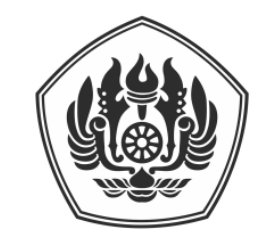

\author{
Padjadjaran Journal of International Law \\ ISSN: 2549-2152, EISSN: 2549-1296 \\ Volume 3, Number 1, January 2019
}

\title{
ASEAN Reform: Towards a More Cohesive Regional Intergovernmental Organisation
}

\begin{abstract}
Yogi Bratajaya*
\section{Abstract}

The Association of Southeast Asian Nations (ASEAN) is a regional intergovernmental organization that has seen exponential growth throughout the course of its lifespan ever since it was founded in August 8 of 1967. The organization comprises of 10 Member States with differing backgrounds in economy, culture and government. Its aims and purposes include "To promote regional peace and stability through abiding respect for justice and the rule of law in the relationship among countries of the region and adherence to the principles of the United Nations Charter" based on the "Mutual respect for the interdependence, sovereignty, equality, territorial integrity, and national identity of all nations." However, it seems that ASEAN's fundamental principles are its main detriment to achieving and carrying out its aims and purposes. The organization has faced multiple criticisms regarding its failure to address pressing matters in the region, such as ongoing human rights violations committed by member states. The slowness in addressing these matters is due to its fundamental principles of non-intervention and mutual respect for political independence, which in turn causes the lack of comprehensive dispute settlement mechanisms within the organization. This journal aims to pinpoint and identify the root of the aforementioned problems and seeks to provide a comprehensive solution with reference to other regional organizations.
\end{abstract}

Keywords: ASEAN, Legal Personality, Dispute Settlement, Human Rights

\section{Reformasi ASEAN: Menuju ke Organisasi Regional Antar-Negara yang Lebih Kohesif}

\begin{abstract}
Abstrak
Association of SouthEast Asian Nations (ASEAN) merupakan sebuah organisasi antarnegara regional yang mengalami perkembangan pesat sejak terbentuknya pada 8 Agustus 1967. Saat sekarang ASEAN mengandung 10 anggota negara yang mempunyai latar-belakang ekonomi, budaya, dan sistem pemerintahan yang berbeda. Tujuan dari ASEAN adalah "To promote regional peace and stability through abiding respect for justice and the rule of law in the relationship among countries of the region and adherence to the principles of the United Nations Charter" berdasarkan "Mutual respect for the interdependence, sovereignty, equality, territorial integrity, and national identity of all nations." Namun, prinsip dasar ASEAN seakan-akan menghambat ASEAN untuk mencapai tujuannya. Kritik yang dihadapi oleh ASEAN meliputi statusnya dalam hukum internasional, kurangnya efektivitas sistem penyelesaian sengketa di dalam ASEAN, dan bagaimana ASEAN mengatasi permasalahan Hak Asasi Manusia. Jurnal ini bertujuan untuk mengidentifikasi masalah tersebut dan memberi solusi komprehensif dengan meninjau kepada organisasi regional lain.
\end{abstract}

Kata Kunci: ASEAN, Personalitas Hukum, Penyelesaian Sengketa, Hak Asasi Manusia

PADJADJARAN JOURNAL OF INTERNATIONAL LAW Volume 3 Number 1 Year 2019 [ISSN 2549-2152] [e-ISSN 2549-1296]

Undergraduate Student Faculty of Law Universitas Padjadjaran, Jalan DipatiUkur Nomor 35 Bandung, ybratajaya@gmail.com, (Universitas Padjadjaran). 


\section{A. INTRODUCTION}

The rise of regional organizations around the globe has sparked increased cooperation and multilateralism between states located in the same geographical region. Joseph Nye defined an international region as a "limited number of states linked together by a geographical relationship and a degree of mutual interdependence" and regionalism as "the formation of interstate groupings on the basis of regions". ${ }^{1}$ Regional organizations are characterized by two main elements: geographical proximity and solidarity founded on common interests and shared values. ${ }^{2}$

However, some regional organizations are not bound by rigid geographical limits and may encompass States from varying geographical regions. As such, there may not be a direct geographic relationship between State members of the same regional organization, but rather an indirect geographical connection. One example of such an organization is the Northwest Atlantic Fisheries Organization (NAFO), which includes member States of different geographic locations such as Cuba, France, Canada, Russia, Japan, the Republic of Korea, Denmark, Norway, Iceland, Ukraine and the United States. These States are not particularly geographically proximate as many of them are on different continents. Rather, the member States share an indirect geographical connection arising from the fact that they all fish in the Northwest Atlantic Ocean. Hence, the creation of the regional organizations in this context appears rather as a fact of nature than an act of the will of States as such. ${ }^{3}$

Another key factor for the formation of regional organizations is that of solidarity, which is also characterized by the term "interdependence". ${ }^{4}$ States are grouped within regional organizations in order to

Joseph Nye, International Regionalism, Boston: Little, Brown and Co, 1968, p. vii.

Laurence Boisson de Chazournes, Interactions between Regional and Universal Organizations: A Legal Perspective, Leiden: Brill Nijhoff, 2017, p. 8. achieve objectives that they cannot achieve through national mechanisms or through universal organizations. States decide to group together under a collective interest, which is not merely the pursuit of national policy objectives, but an objective that requires the individual States to act in cooperation with each other. One example of a collective interest among different States would be the interest to achieve greater security within the region. The vast majority of States have joined the collective security system established by the United Nations, but they nevertheless remain attentive to their own security needs and thus may favour a regional union with countries sharing a similar vision in respect of security. When States decide to form a regional organization there is a degree of interdependence among them, imposing upon member States equal obligations that must be fulfilled to realize its goals. An example of the existence of this interdependence is found in regional free trade organizations such as MERCOSUR or the Asia-Pacific Economic Cooperation (APEC). It is also found in some regional organizations with a political and economic vocation, such as the Association of Southeast Asian Nations (ASEAN).

Regional organisations link together geographically and ideologically related states, and has since the close of the Second World War seen an increase in its proliferation. This proliferation is due to a number of factors: first, the onset of the Cold War and the failure of the Security Council's enforcement procedures stimulated the growth of regional defence alliances (such as NATO and the Warsaw Pact) and bloc politics. Second, the decolonisation process resulted in the independence of scores of states, most of which were eager to play a non-aligned role between East and West, and the rise of

Ibid, p. 10.

Ibid, p. 12 
globalisation has meant that all states form part of one economic trading system and can no longer individually function effectively, thus precipitating the evolution of regional economic arrangements. ${ }^{5}$

Regional organizations have the same elements and characteristics as that of international organizations, consistent with the definition of an international organization by $M$. Virally, which is "an association of States, established by agreement among its members and possessing a permanent system or set of organs, whose task is to pursue objectives of common interest by means of cooperation among its members". 6 Jan Klabbers states that although there is no strict definition of an international organization, most international organizations share the same characteristics and elements which are: created between States, on the basis of a treaty, and contain an organ with a distinct will. ${ }^{7}$ Furthermore, the International Law Commission (ILC) in its work on the responsibility of international organizations, the definitions of an international organization under international law are formulated to meet a purpose, and not "all purposes". Their scope is therefore relative.

ASEAN was founded on 8 August 1967. The founding Member States included Indonesia, Philippines, Malaysia, Singapore and Thailand. The Association was first enlarged after Brunei was admitted on 7 January 1984 , after attaining independence from the United Kingdom. That there are no permanent friends or foes in international relations was reaffirmed when Vietnam became an ASEAN member on 28 July 1995, despite a decade of antagonisms. Laos and Myanmar became Member States on 23 July 1997. Cambodia was the last to join on 30 April 1999. ASEAN's purpose fundamentally is to reduce conflict between
Southeast Asian States and to facilitate regional stability within the greater East Asian region. In order to accommodate this, three agreements were signed in 1967: a Treaty of Amity and Cooperation, which reaffirmed the parties' commitment to peace and dealt with the peaceful settlement of disputes; the Declaration of ASEAN Concord, which called for increased political and economic coordination and cooperation; and the Agreement of Establishment of the Permanent Secretariat to coordinate the national secretariats established under the 1967 ASEAN Declaration. In 1987, the Protocol amending the Treaty of Amity was signed, under which countries outside the ASEAN region could accede to the treaty. A number of economic agreements have also been signed, ranging from the Manila Declaration of 1987 to the Framework Agreement on Enhancing ASEAN Economic Co-operation, 1992 and the decision to establish an ASEAN Free Trade Area within fifteen years utilising a Common Effective Preferential Tariff scheme. In 2003, ASEAN Concord II was signed, establishing the ASEAN Security Community, Economic Community and Socio-Cultural Community.

While ASEAN has so far been successful in facilitating dialogue between its member States and increasing economic prosperity of the region, to this day still a number of problems plague ASEAN. Those problems include, inter alia, the legitimacy and legal personality of ASEAN as a regional intergovernmental organisation, the minimum effectiveness or lack thereof of a coherent dispute settlement mechanism, and criticisms surrounding its role in ensuring and maintaining human rights. This article will address such issues and provide recommendations as to how ASEAN can be improved.

\footnotetext{
Malcolm N. Shaw, International Law, New York: Cambridge University Press, 2008, p. 1287.

$6 \quad$ Laurence Boisson de Chazournes, Op Cit, p. 22.
} 


\section{B. ASEAN AS A REGIONAL INTERGOVERNMENTAL ORGANISATION}

As ASEAN matures, its preference for loose arrangements over legally binding documents has created practical problems. The measured pace of institutional building, itself indicative of the consensual approach in which such decisions are made, has struggled to keep up with the nature and pace of integration (especially its economic agenda) within the Association. A recurring issue as ASEAN progresses was the uncertainty surrounding ASEAN's legal personality under international law. Neither the Bangkok Declaration of 1967 nor subsequent instruments such as the TAC clarified this issue as these documents did not expressly provide for ASEAN's legal personality. ${ }^{8}$ To address this issue, member States formulated the ASEAN Charter which was adopted on 20 November 2007. The ASEAN Charter adds to the declaration by laying out the structural foundations of ASEAN as a regional organisation.

The Charter must be ratified by all member States. By concluding a legally binding agreement, ASEAN's leaders have signalled their commitment to a catalogue of legal obligations and rights. However, the Charter's design elements are correlated where its substantive (deep or shallow obligations), structural (binding or nonbinding) and review (strong or weak enforcement) elements are closely linked. Furthermore, the Charter has been carefully drafted to preserve the sovereignty of each member State as the ultimate source of authority that enacts and enforces laws within their territorially defined units. ${ }^{9}$ Respect for sovereignty and a strict adherence to the principle of nonintervention are the foundational principles

Daniel Seah, “I. THE ASEAN CHARTER”, International and Comparative Law Quarterly (2009), 58, page 197-

212.

$9 \quad$ lbid. of the ASEAN and dictates how the organization operates. ${ }^{10}$

International legal personality is thought to be a conditio sine qua non for the possibility of acting within a given legal situation. An international organization's legal personality affects its capacity under international law to enter into relations with other organizations or States and also their competence to conclude treaties. Personality is considered to be a threshold, which must be crossed, without international legal personality, an international organization is unable to start proceedings under international law against a State. The point of Legal personality is an individual that does not live solely as individuals or in the form called the state (which is an abstraction). Instead, they form affiliations for various purposes: practical political or both. Some type of recognition is often strived for to protect these affiliations from interference, and this recognition often takes the form of an entity's legal personality.

The legal capacity conferred to an international organization entails that international organization to exercise their rights under international law. The endowment of legal capacity may be inherent subsequent to obtaining legal personality, or it may be determined by the constitution of the organization and must be related to its function. This extent of this legal capacity was reaffirmed by the ICJ in the Reparation for Injuries Case where the Court held that, "hereas a State possesses the totality of international rights and duties recognized by international law, the rights and duties of an entity such as the Organization must depend upon its purposes and functions as specified or implied in its constituent documents and developed in practice". ${ }^{11}$ This judgment is groundbreaking as it recognized the

10 Article 2, Treaty of Amity and Cooperation in Southeast Asia Indonesia.

11 Reparation for injuries suffered in the service of the Nations, Advisory Opinion, [1949] ICJ Rep 174. 
international personality and capacity of international organizations, in that case the United Nations.

ASEAN's legal personality can be found expressly within Article 3 of the ASEAN Charter, which helps to build a foundation for the external perceptions of ASEAN as a political actor on the international plane even though the precise nature of its legal character might still be unclear. ${ }^{12}$ This is true even if one accepts the view that the Charter (when it enters into force) does not radically alter the substance of ASEAN's competence under international law. A former ASEAN Secretary-General has described the 'real handicap' of persuading multinational corporations to contribute funding support to ASEAN projects since the Association, which apparently lacked legal personality, could not claim tax exemption status as a non-profit organization in the domestic laws of the Member States.

In its conduct of external relations, Article 41(7) of the ASEAN Charter provides that 'procedures for concluding such (international) agreements shall be prescribed by the ASEAN Coordinating Council in consultation with the ASEAN Community Councils. ${ }^{13}$ Three remarks are noteworthy. First, the ASEAN Charter pointedly does not include these specific powers for its institutions, such as the ASEAN Secretariat. This significantly differs with other regional organisations, such as the European Union (EU), in which the EU Commission may within its area of competence represent and act for the Union in trade negotiations and enact legal instruments which are directly binding upon its member States. Secondly, the ASEAN Secretary-General has in practice concluded agreements on behalf of the Association. For example, a Memorandum of Understanding (MOU) which was concluded between the governments of ASEAN member States and China on cultural cooperation was signed on behalf of ASEAN

Art. 3 ASEAN Charter

13 Art. 41(7) ASEAN Charter. by the Secretary-General and a Chinese representative on 3 August 2005. Thirdly, Articles 11 and 41 of the ASEAN Charter does not provide clearly on the manner in which important agreements such as the China-ASEAN Free Trade Agreement (CAFTA) would be concluded in the future.

Decision-making is in principle enshrined in Article 20(1) of the ASEAN Charter to be by consultation and consensus. ${ }^{14}$ This is known as the 'ASEAN Way', and is characterized by an informal, personal working style. Policymakers and politicians have evolved habits of compromise, consensus and consultation. The recognition that member States are sovereign equals under international law, who enjoy procedural parity within ASEAN, is also underscored in the equal annual contributions to the operational budget of the ASEAN Secretariat. Consensus in decision-making has a protean quality. Consensus does not necessarily require unanimity. Explicit consent to a decision is not necessary for consensus to be forged, although the latter might be blocked if one or more ASEAN members felt the decision would militate against their national interests. Consensus on a decision can also be reached despite misgivings from one or more member States. Other international or regional organizations such as the UN and European Union EU also operate on the basis of consensus. Where they differ from ASEAN is that these organizations have formal voting or procedural mechanisms to break the impasse, if consensus fails. This 'ASEAN Way' is the manifestation of the integral principles of non-intervention. While the ASEAN is based on mutual respect for each member's sovereignty, this way of negotiations based on consensus may pose as an impediment towards the organization's capacity to address certain pressing matters, on the basis that if a consensus cannot be reached then no progress can be made.

14 Art. 20(1) ASEAN Charter. 
The supreme policy-making body of ASEAN is the Summit, comprising the Heads of State or Government, with a Coordinating Council composed of Foreign Ministers. The ASEAN Summit's responsibilities are twofold as the supreme policy-making body. First, pursuant to Article 20(2) of the ASEAN Charter ASEAN's leaders have the discretion to decide how a 'specific decision can be made' if consensus cannot be achieved. ${ }^{15}$ Of course, the option to force a vote is left open: the Charter neither endorses nor prohibits the ASEAN Summit from voting to break an impasse in decision-making. The second function of the Summit is to resolve disputes peacefully between its member States.

\section{DISPUTE RESOLUTION UNDER THE ASEAN REGIME}

Under Article 20(4), a 'serious breach' of the Charter or non-compliance shall be referred to the Summit. ${ }^{16}$ In this respect, Article 22(1) further provides that Member States 'shall endeavour to resolve peacefully all disputes in a timely manner through dialogue, consultation and negotiation. ${ }^{17}$ In terms of the Charter's design elements (form, structure and substance), then, its review structure is weak: there is no express provision for sanctions in the event of noncompliance. This was extensively discussed by ASEAN leaders and it was ultimately decided that the Summit shall be given the widest flexibility on how they might wish to proceed with violations, which includes human rights issues. Articles 22 and 23 also provide that member States may also at any time agree to utilize good offices, conciliation or mediation in the same manner within an agreed time limit. In this regard, the Chairman or the SecretaryGeneral of ASEAN may be requested to act as a third person in these processes.

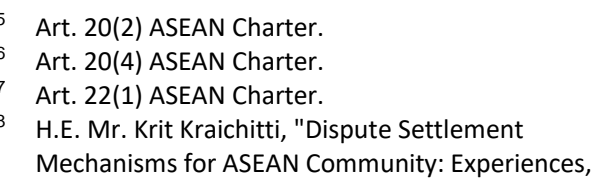

It is important to note that the Charter does not impose an undertaking to the compulsory settlement of disputes upon Member States but in keeping with their obligations under general international law Member States 'endeavour to resolve peacefully all disputes in a timely manner through dialogue, consultation and negotiation'. The Member States still retain their autonomy therefore but the Charter could be said to play the role of a 'facilitator'.

In accordance with Article 27(1) of the ASEAN Charter, compliance with the outcome of a dispute settlement mechanism, either an arbitral award or settlement agreement, is monitored by the Secretary-General of ASEAN. In the event of non-compliance, an affected Member State may refer the matter to the ASEAN Summit for decision, thus endowing it with 'quasijudicial oversight'. Such recourse to a third authority is not an uncommon feature. In April 2012 Rules for Reference of NonCompliance to the ASEAN Summit were adopted in order to provide guidelines as to the procedures to be applied in instances of non-compliance. The Rules for Reference provide yet another example of ASEAN's 'quiet diplomacy'. Before a case of noncompliance can be submitted to the ASEAN Summit the ASEAN Coordinating Council must seek to facilitate discussions between the disputants with a view to securing compliance. Only where such intervention fails to secure an outcome is the matter to be referred to the ASEAN Summit by the ASEAN Coordinating Council along with its recommendations. ${ }^{18}$

Besides the ASEAN Charter, there are other instruments promulgating dispute settlement mechanisms for its member States. These are the Treaty of Amity and Cooperation in Southeast Asia of 1976 (TAC), ASEAN Protocol on Enhanced Dispute

\footnotetext{
Challenges and Way Forward", Workshop on Trade and Investment ASEAN Law Association 12th General Assembly, Manila, Republic of the Philippines, 25-28 February 2015.
} 
Settlement Mechanism of 2004 (EDSM), Protocol to the ASEAN Charter on Dispute Settlement Mechanisms of 2010 (ACDSM), and Investor-State Dispute Settlement (ISDS) under the ASEAN Comprehensive Investment Agreement (ACIA).

\section{Treaty of Amity and Cooperation in Southeast Asia of 1976 (TAC)}

The TAC is the first ASEAN legal instrument which elaborates on dispute resolution mechanisms for resolving the disputes that arise from application of the treaty from political, security, economic, social cultural and over all areas of relations among Member States. According to the TAC, member States shall refrain from the threat or use of armed force against each other, and shall resort to settlement of disputes amicably through negotiations. If the disputes cannot be resolved through negotiation, disputing parties may submit it to the High Council, which is a ministerial meeting of member states of TAC, to consider the issue and make recommendations on the appropriate means of settlement. The High Council may also offer to act as a mediator to resolve the disputes by good office, mediation, inquiry or conciliation.

2. ASEAN Protocol on Enhanced Dispute Settlement Mechanism of 2004 (EDSM) Under the EDSM, the settlement of disputes is initiated by a request for consultation by a Member State. Such consultation is a mandatory and prerequisite step to provide an opportunity for the parties to discuss the issue towards a mutually acceptable solution before entering litigation processes, and should be done within sixty days from the receipt of the request unless the parties agree otherwise. If the consultation fails to settle the dispute in such a time frame, the matter shall be raised to the ASEAN Senior Economic Officials Meeting (SEOM) by a request from the complaining party to establish a panel. The SEOM shall then establish a panel unless the SEOM decides otherwise by consensus (the so-called "reverse consensus"). The recourse under the EDSM, however, does not prevent member States from resort to other voluntary dispute settlement mechanisms such as good offices, conciliation and mediation.

3. Protocol to the ASEAN Charter on Dispute Settlement Mechanisms of 2010 (ACDSM)

While the ASEAN Charter merely sets out general principles for the resolution of disputes between its member States, it is the ACDSM that puts in place such an institutionalized system and provides specified dispute resolution methods. The Protocol reaffirms that it applies to disputes concerning the interpretation or application of the Charter, other ASEAN instruments which expressly state that the Protocol, or part thereof, applies or other ASEAN instruments unless specific means of dispute settlement are already provided for. Again States parties are encouraged to make every effort to reach a mutually agreed solution to their dispute. The term 'dispute' is not defined either in the Charter or the Protocol but the fact that Article 22(1) of the Charter refers to 'all disputes' points toward legal and political differences arising over the Charter coming within the Protocol' $s$ ambit. Whilst arbitration may constitute the most suitable procedure for handling legal disputes there is nothing in the Charter or the Protocol to suggest that arbitration is restricted to legal disputes.

Only States parties may have recourse to the Protocol and, like other similar treaties, parties commit themselves in advance to the possibility of submitting certain categories of dispute to the settlement modes set out therein. However, submission of a dispute to any of the available procedures rests in the main on double 
consent. This is because, first, acceptance of the Protocol is a voluntary exercise of State sovereignty, which must be ratified by all the Member States to enter into force, and secondly, because in each specific instance the respondent State must agree to the dispute being submitted to the procedures. However, there appears to be an important exception to this general rule. The use of mandatory terms, the verb 'direct' and the noun 'direction', in Articles 9(1) and 10(1) of the ACDSM suggests that in a very specific, limited circumstance the ASEAN Co-ordinating Council can ultimately compel the refusing party to submit to one of the methods contemplated under the ACDSM. Of course, all the parties will have accepted this procedure ante hoc since the Protocol requires unanimity to come into force. The Protocol may therefore be said to contain elements of both choice and compulsion, although overwhelmingly the former. The ACDSM is applicable to inter-State disputes only, concerning the State as a direct party and consequently does not provide for so-called mixed arbitrations.

The ACDSM provides for formal techniques for dispute resolution which range from the time-honoured diplomatic, or political, processes, that is, consultation, to good offices, mediation and conciliation, to the quasijudicial, arbitration. The general rule is that the former procedures cannot result in the imposition of binding decisions and are but advisory, while the latter does. ${ }^{19}$ It is interesting to note that, unlike the TAC, inquiry, or factfinding, is not specifically mentioned in the Protocol. Neither does the ACDSM make provision for a court. However, given that arbitration is an available

19 Gino J. Naldi, "The ASEAN Protocol on Dispute Settlement Mechanisms: An Appraisal", Journal of International Dispute Settlement, 2014, 5, pp. 105-138. option this omission may not presently amount to a fatal flaw.

4. Investor-State Dispute Settlement (ISDS) under the ASEAN Comprehensive Investment Agreement (ACIA).

Under Article 28 of the $A C I A$, investors of an ASEAN member State, either natural or juridical persons, are able to bring a claim against the government of another ASEAN member State for the loss or damage to their investment resulting from the breach of obligation under the Agreement. In addition to State to State level dispute resolution, the ACIA also provides a dispute settlement mechanism between states and investors. ACIA dispute settlement mechanism process begins with consultation and negotiation, and if the dispute has not been resolved within 180 days of the receipt of a request for consultations, the disputing investor can submit an arbitration claim to the courts or administrative tribunals which have jurisdiction over such claim or other international arbitration rules and institutions. ACIA provides very detailed process of arbitration proceedings which gives a clear roadmap to disputing parties. It is important to note that disputing parties still can, at any time during the process, agree to conciliation. Furthermore, the ISDS under ACIA also applies to foreign investors constituted or organized under the applicable laws of member States, i.e. foreign-owned ASEAN-based companies.

\section{PROBLEMS AND SOLUTIONS TO THE SETTLEMENT OF DISPUTES UNDER THE ASEAN REGIME}

Despite ASEAN dispute settlement mechanisms having been well established by many ASEAN Treaty Agreements from 
TAC to Enhanced DSM with clear and detailed procedures and timelines as described above, for some reason, ASEAN member States have never resorted to such mechanisms as of yet. Instead, member States prefer to settle their disputes by rulebased DSM which is more reliable, predictable and practical such as those of the World Trade Organization and International Court of Justice. Until now, all disputes between ASEAN Member States have been resolved through the consultations and subject matters are merely misunderstandings that did not require adjudication processes. This outcome may be linked to multiple factors including but not limited to the lack of legal certainty, the so called 'ASEAN Way', and the different approaches of ASEAN countries towards the recognition and enforcement of foreign arbitral awards. ${ }^{20}$

However the most notable cause for the lack thereof ASEAN member States resorting to the ASEAN dispute settlement mechanisms is the impractical nature of the dispute settlement mechanisms themselves. This can be attributed towards several elements. First, short time frames, where in each process of the ASEAN dispute settlement mechanism there are difficult time frames placed to be met in practice. For example, a sixty-day timeframe for the panel to submit reports is unrealistic, especially when compared with those of WTO practice which normally takes up to fourteen months from panel establishment to the circulation of the report. Since the panel will have to go through many procedural steps from its establishment, exchange of written submissions, meetings with the parties, and drafting an interim report before submitting it to the SEOM. Also, there may be the case where the panel wishes to seek expert advice which may take more time. Second, under Article 26 of the ASEAN Charter, a dispute which remains unresolved after the application of ASEAN dispute settlement mechanisms shall be referred to the ASEAN Summit, a political body held merely twice a year, where the final decision will be made by consensus hence give an opportunity for a review of the dispute. This directly connected to Article 27 of the ASEAN Charter which provides that member States affected by non-compliance of the findings, recommendations or decisions resulting from ASEAN dispute settlement mechanisms are also allowed to refer the dispute to the ASEAN Summit for a political solution, which will in the same way give the same uncertainty as Article 26 thereof. The aforementioned practices are difficult to maintain and result in an unfavourable view by member States towards the ASEAN dispute settlement mechanisms.

There have been suggestions to increase member States to resort to the dispute settlement mechanisms provided by ASEAN including improving rules and procedures of the dispute settlement mechanisms to be more balanced and practical, transparent and cost effective, more rule-based than relation-based system, and enhancing public awareness and knowledge about ASEAN Charter, ASEAN economic agreements, all related ASEAN legal instruments. Other notable suggestions include making ASEAN DSM a rule-based regime rather than relationbased regime (such as the elimination of consensus in decision making process), revision of cost burden in resolving dispute to be similar to the system of WTO where all costs are shared equally by all AMS rather than by disputing parties, and the training of more experts in ASEAN laws and each field of disputes to be used as experts, legal advisors, and arbitrators.

\section{E. ASEAN AND ITS ROLE IN ENSURING HUMAN RIGHTS}

Over the last two decades ASEAN has taken several significant steps towards creating a regional human rights system. The birth of

\footnotetext{
${ }^{20}$ H.E. Mr. Krit Kraichitti, Loc. Cit.
} 
the ASEAN Charter in 2008 and the ASEAN Human Rights Declaration (AHRD) in 2012, as well as the establishment of the ASEAN Intergovernmental Commission on Human Rights (AICHR) in 2009, illustrate this movement. These events are supported by several instruments addressing the rights of women, children, and migrant workers, together with a number of mechanisms designed to implement these instruments. Equipped with this arsenal of instruments and mechanisms, it was hoped that ASEAN would be able to respond more adequately to the violation of rights committed by its member states. Sadly, this has not been the case. Indeed, both ASEAN and the AICHR have remained passive in addressing these wrongdoings, both before and after the above mentioned human rights instruments and mechanisms were put in place. ${ }^{21}$ Before delving into its failures, it is important to understand the instruments put in place by ASEAN to ensure human rights.

On 19 November 2012, the ASEAN adopted the AHRD for the protection and promotion of fundamental rights and freedoms within ASEAN member States. The goal of the AHRD is that, through mutual cooperation and with the assistance of competent entities, Member States have expressed their common interest in safeguarding ASEAN human rights. This interest had already been manifested in Article 1(7) of the ASEAN Charter stipulating that the promotion and protection of human rights is one of ASEAN's purposes as well as in Article 2(2)(i) thereof citing the protection of fundamental freedoms as a governing principle. The AHRD is however only an instrument of a political nature, it is not a legal text entailing binding obligations for Member States.

The AHRD could be described as a modern text as it incorporates all three

21 Hien BUI, "The ASEAN Human Rights System: A Critical Analysis", Asian Journal of Comparative Law/FirstView Article, June 2016, pp. 1 - 30.

22 Gino J. Naldi, "The asean Human Rights Declaration", International Human Rights Law Review, 3 (2014), page 183-208. generations of human rights. This is no coincidence: Asian States have been instrumental in calling for parity to be given to second and third-generation rights, arguing that the totality of rights cannot be dissociated from each other and from the promotion of social justice. This very strong belief is manifested in Article 7 of the AHRD which stipulates that 'All human rights are universal, indivisible, interdependent and interrelated. All human rights and fundamental freedoms in this Declaration must be treated in a fair and equal manner, on the same footing and with the same emphasis.' Thus, the AHRD is inspired partly by the Asian philosophy of rights, which places greater emphasis on the nexus between the individual and the wider community, and focuses on the collective rather than the Western classical theory of human rights, characterized by excessive individualism. ${ }^{22}$

The AHRD is not without its flaws however. Some have stated that the AHRD lack in substance and identity. ${ }^{23}$ That The lead up and form of the Declaration suggests that, while there is agreement about the need for a human rights component within ASEAN, and further agreement that this should not be limited to "just" economic, cultural and social rights, there is no shared commitment to the significance of that inclusion. ASEAN member states value the Declaration for completely different reasons. This divergence is of great importance for arguments about the presence of an ASEAN identity. According to Michael E. Jones, the creation of a regional identity was ambitious and would require a substantial change in, and between, ASEAN member states and the question as to whether ASEAN member states share an identity has

23 Davies, Mathew (2014), “An Agreement to Disagree: The ASEAN Human Rights Declaration and the Absence of Regional Identity in Southeast Asia", Journal of Current Southeast Asian Affairs, 33, 3, pp. 107-129. 
been much debated. ${ }^{24}$ Framing the Declaration as an incompletely theorised agreement indicates that human rights, where the agreement to disagree dominates, play no role in any shared regional identity that may currently exist. There is no agreement upon which that shared identity could rest. Any common identity that includes human rights would, by definition, have to demonstrate a convergence between member state positions on the matter and an adherence to the established regional standards, neither of which are present. The presence of a written document cannot be used as evidence for a regional identity simply because it has ten signatures attached to it, because the reasons for signing can diverge significantly. Furthermore, unlike other regional human rights instruments, such as the European Convention on Human Rights or the American Convention on Human Rights, the AHRD is non-binding and thus does not have the legal power to compel member States to adhere towards its provisions. This creates a significant legal gap in the imposition of international human rights obligations and standards towards ASEAN member States, and its consequence can be felt by the fact that for the past few years ASEAN members have increasingly committed egregious violations of human rights with impunity. Examples include the Philippine's excessive war on drugs, which is now under investigation by the International Criminal Court, and Myanmar's ethnic cleansing of the Rohingnya population, which is also under investigation by the ICC. ${ }^{25}$

Regardless of the existence of an instrument, much of the criticism stems from the ASEAN's response, or more appropriately passivity in handling matters when its Member States blatantly violate human rights. One recent example is their handling of the blatant human rights abuses

24 Michael E. Jones, 'Forging an ASEAN Identity: The Challenge to Construct a Shared Destiny' (2004) Contemporary Southeast Asia 26, 1, p. 152. by Myanmar. The decision to accept Myanmar's membership into ASEAN was already initially criticized, seeing its history with violating human rights from when the military regime ruled it in 1962 until 2011. Those who support ASEAN's stance on Myanmar generally espouse a view similar to that of Lee Jones, who argues that ASEAN's efforts are best understood as an effort to "insert itself" into political and human rights issues in Myanmar as a means of promoting liberalization and human rights in the country. His position is based on a theory of "constructive engagement" with non-compliant states, and is in line with statements made by former Vietnamese Foreign Minister Mr Nguyen Dy Nien, who affirmed that "ASEAN is trying to democratize Myanmar".

But while advocates of constructive engagement argue that "only by engaging with Myanmar can outsiders encourage democratic change", they do not seem to take the actual results - that is, the efficacy of actions taken to improve Myanmar's human rights situation - into consideration. Clearly, the fact that human rights violations actually worsened in the years after Myanmar joined ASEAN suggests that any attempt at constructive engagement was ineffective in this case. This fact shows that even though ASEAN might not have remained totally inactive, it did not bring about any positive results. ${ }^{26}$

Mann Bunyanunda argues that ASEAN's decision to include Myanmar in the organization as a means of constructively engaging with the government constitutes proof of its failure to improve the human rights situation in the country. Bunyanunda reaches this conclusion by comparing the situation in Myanmar during the period it was accepted as an ASEAN member state to that when constructive engagement was introduced. Other have gone so far as to state that instead of stopping rights

\footnotetext{
25 International Criminal Court, 'Bangladesh/Myanmar' <https://www.icc-cpi.int/bangladesh-myanmar>

26 Hien BUI, Loc. Cit.
} 
violations in Myanmar, ASEAN has actually supported - or even "embraced" - the junta, thereby "prolong[ing] its tenure".

The failure of ASEAN to ensure human rights and prevent or hold accountable member States to comply with human rights provisions is directly linked to the procedural challenges and lack of power that ASEAN bodies have such as the AICHR. First, there is a lack of indepence of the AICHR. The AICHR is merely "a consultative intergovernmental body." As a consultative body, the AICHR is structured in such a way that it functions to accommodate its close relationship with governments. Regarding this point, the AICHR's Terms of Reference (TOR) provide procedures which are problematic. Firstly, it requires that the representative of the member state that chairs ASEAN will also lead the AICHR in the same year. Secondly, the ASEAN Foreign Ministers make all final decisions on amending, reviewing, and interpreting the AICHR's functions and mandates. And lastly, the member states' governments are responsible for nominating and replacing the members of the AICHR, who "shall be accountable to the appointing Government. 27

The second procedural hurdle that the ASEAN must overcome is that of weak protection mandates. Phan Duy Hao is one of the scholars who indicates that the AICHR only concentrates on "promotional work" and not on its protection mandate. In his exact words, he claims that the "AICHR fails to recognize the concept of the responsibility to protect". Indonesia's commissioner to the AICHR, Rafendi Djamin, confirms Phan's argument by stating that the AICHR does not have the authority to undertake investigations of human rights violations. In order to justify the claim that the AICHR lacks a protection mandate, it is important to understand which mandates a regional commission for human rights would need in order to fulfil its responsibility to protect. ${ }^{28}$ The African

\footnotetext{
27 Hien BUI, Loc Cit.
}

Commission, for example, has performed its obligation to protect through different mandates. The mandates involve receiving communications about violations of rights, communicating them to states, and investigating the violations.

In order to more effectively build ASEAN's role as a cornerstone of human rights, besides changes towards the AICHR some have also called for the establishment of an ASEAN Court of Human Rights. Similar to the European Court of Human Rights, the Inter-American Court of Human Rights or the African Court on Human and Peoples' Rights, the establishment of a judicial body is necessary in order to ensure that States comply with the obligation to respect, protect and fulfill human rights. The European Court of Human Rights for example has been found to be very effective in dealing with human rights issues and ensuring that member States of the Council of Europe comply with the provisions of the European Convention on Human Rights. It is now up to the pro-activity of ASEAN member States and ASEAN itself for the full realisation of human rights within its Member States.

\section{F. CONCLUSION}

ASEAN, as a regional intergovernmental organization still has a long way to go if they want to be regarded to be of the same quality and standard as the likes of the European Union, African Union, or the Organization of American States. It must provide more coherency internally as an organization before it can project itself onto the international community. As an organization with Member States of such differing backgrounds economically, politically, and culturally, it is indeed important to put forward mutual respect for each Member State's sovereignty and political independence. However, with the increase of globalization and multilateralism it is now more than ever

28 Hien BUI, Loc. Cit. 
that people share the same values, especially in regards to human rights. With this in mind, it would be most desirable for ASEAN to implement more coherent and systemic procedures of not only legislation/treaty-making processes but also of dispute-settlement. Without departing fully from the fundamental principles that shape ASEAN, it is worth considering if the "ASEAN Way" may be departed in favor of a more streamlined process which does not rely on the consensus of each and every single member State in order to enact agreements that address pressing matters. More importantly, more power and independence should be given towards its bodies, such as the AICHR, so that it may actually carry out its functions and goals in a meaningful manner, unshackled by the constraints of having to adhere to the will of member states. If these reforms cannot be realized, then ASEAN's reputation and standing as a regional intergovernmental organization is ultimately at stake.

\section{REFERENCES}

\section{Books}

Jan Klabbers, An Introduction to International Organizations Law $3^{\text {rd }}$ Edition. Cambridge: Cambridge University Press, 2015

Joseph Nye, International Regionalism, Boston: Little, Brown and Co, 1968.

Laurence Boisson de Chazournes, Interactions between Regional and Universal Organizations: A Legal Perspective, Leiden: Brill Nijhoff, 2017.

Malcolm N. Shaw, International Law, New York: Cambridge University Press, 2008.

\section{Other Documents}

Daniel Seah, "I. THE ASEAN CHARTER", International and Comparative Law Quarterly (2009), 58, page 197-212.

Davies, Mathew (2014), "An Agreement to Disagree: The ASEAN Human Rights Declaration and the Absence of Regional Identity in Southeast Asia", Journal of
Current Southeast Asian Affairs, 33, 3, page 107-129.

Gino J. Naldi, "The asean Human Rights Declaration", International Human Rights Law Review, 3 (2014), page 183208.

Gino J. Naldi, "The ASEAN Protocol on Dispute Settlement Mechanisms: An Appraisal", Journal of International Dispute Settlement, 2014, 5, page 105138.

H.E. Mr. Krit Kraichitti, "Dispute Settlement Mechanisms for ASEAN Community: Experiences, Challenges and Way Forward", Workshop on Trade and Investment ASEAN Law Association 12th General Assembly, Manila, Republic of the Philippines, 25-28 February 2015.

Hien BUI, "The ASEAN Human Rights System: A Critical Analysis", Asian Journal of Comparative Law/FirstView Article, June 2016, page 1 - 30.

International Criminal Court, 'Bangladesh/Myanmar' <https://www.icc-cpi.int/bangladeshmyanmar $>$.

Michael E. Jones, 'Forging an ASEAN Identity: The Challenge to Construct a Shared Destiny' (2004) Contemporary Southeast Asia 26, 1.

\section{Legal Documents}

ASEAN Comprehensive Investment Agreement ( $\mathrm{ACI} A)$.

ASEAN Human Rights Declaration 2012 (AHRD).

ASEAN Protocol on Enhanced Dispute Settlement Mechanism of 2004 (EDSM).

Charter of the Association of Southeast Asian Nations 2007 (ASEAN Charter).

Protocol to the ASEAN Charter on Dispute Settlement Mechanisms of 2010 (ACDSM).

Treaty of Amity and Cooperation in Southeast Asia of 1976 (TAC). 